\title{
Growing gap in population dynamics, closing the gap in population size: the European Union and the United States compared
}

\author{
JIŘINA KOCOURKOVÁ ${ }^{1}$, LUDĚK ŠÍDLO ${ }^{1}$, MARTIN NOVÁK ${ }^{1}$, LUDĚK SÝKORA ${ }^{2}$
}

\begin{abstract}
${ }^{1}$ Charles University, Faculty of Science, Department of Demography and Geodemography, Prague, Czechia; e-mail: jirina.kocourkova@natur.cuni.cz,ludek.sidlo@natur.cuni.cz,martyn.novak@ gmail.com

${ }^{2}$ Charles University, Faculty of Science, Department of Social Geography and Regional Development, Prague, Czechia; e-mail: sykora@natur.cuni.cz
\end{abstract}

ABSTRACT This paper investigates differences in population development in the European Union and the United States. The population projections recently published by the United Nations forecast expected a slowdown in growth and a shrinking of the EU population and a continued growth in the US. Therefore, the paper aims to find out which components of population change are primarily responsible for the different population dynamics. The article first explores the role of population change and migration in total population growth. Then it investigates fertility and mortality patterns, focusing on demographic behaviour of ethnic/racial groups in the US and regional disparities in Europe. The paper documents that fertility differences primarily cause the different population dynamics in the EU and the US. This is reflected in the forecast convergence towards the same population size.

KEY WORDS population dynamics - European Union - United States - fertility - mortality migration - regional differentiation

KOCOURKOVÁ, J., ŠíDLO, L., NOVÁK, M., SÝKORA, L. (2018): Growing gap in population dynamics, closing the gap in population size: the European Union and the United States compared. Geografie, 123, 1, 37-62.

Received January 2017, accepted July 2017.

CC Česká geografická společnost, z. s., 2018 


\section{Introduction}

This paper investigates the population development of the two traditional world superpowers: the European Union and the United States. Their sustained population growth since World War Two and favorable age structure consisting of a high number of economically active people have been seen as key factors behind their economic success (e.g. Prskawetz, Lindh, eds. 2007; Cincotta, Engelman 1997). However, despite their political and economic dominance, the US and the EU today account for only $11 \%$ of the world's population (PRB 2015). It is expected that this proportion will further decline, especially in the case of the European Union (UN 2015).

Over the past few decades, significant differences have emerged between the population dynamics and developments in the US and the EU. Thanks to a longstanding annual population increase achieved through natural growth and, in recent decades, the growing role of migration, the population of the EU reached 500 million inhabitants in 2010 (Fig. 1). However, the EU's annual population growth is lower than that of the US, it has slowed down and is expected to reverse (UN 2015). Consequently, although the current difference between the population of the EU and the US is more than 180 million in favor of the EU, the recent UN population projection indicates that at the end of this century the two macroregions will converge in their population size (UN 2015).

While they both exhibited progressive age structures in the 1960s, the proportion of adult aged 65 and older increased in the EU population faster than in the US population by 2015 (Fig. 2). It is forecasted that the age pyramid of the EU population will change to regressive by 2060 . In contrast, the US population structure will stabilize as proportions of pre-reproductive and post-reproductive parts will remain balanced (UN 2015).

Population change and structure are becoming more politically, economically, socially and culturally important. In the EU, demographic ageing is seen as undermining economic strength due to the financial demands of the growing number of beneficiaries of pensions and health care, and social and long-term care (European Commission 2015a). Furthermore, the expected EU population development may threaten the EU goals defined in the Lisbon Strategy, which aim to transform the EU into the most competitive economy in the world while preserving the European social model, and which were reformulated in the Europe 2020 Strategy for smart growth, more social inclusion and environmental sustainability. The impact of demographic change on employment and economic growth has become a major recent policy concern for the EU and its Member States due to the expected decline in the working age population (Peschner, Fotakis 2013; European Commission $2015 \mathrm{~b}$ ) and the recent weakness of Europe's productivity when compared with its main global competitors, especially the US (Fotakis, Peschner 2015; Rincon-Aznar 
et al 2014; van Ark et al 2013). Future economic growth is a necessary precondition for maintaining high social welfare standards, especially in the context of ongoing demographic ageing. While it is expected that the EU and the US will experience an increase in dependency ratio, the absolute number of people of working age will continue to increase in the US, while in the EU it has been falling since 2010 (Peschner, Fotakis 2013; European Commission 2015b). Since we are primarily concerned with the population development in the EU, the US serves as a benchmark against which the EU is compared.

The UN population projections are based on the current population structures and assumptions about the future paths of fertility, mortality and international migration (UN 2015). Since both current age structures and future trends reflect the nature of demographic behavior determined by the path of population development of past decades, we investigate the character and trajectories of population dynamics in the EU and the US since 1960. Our main aim is to ascertain which components of population change are primarily responsible for the different

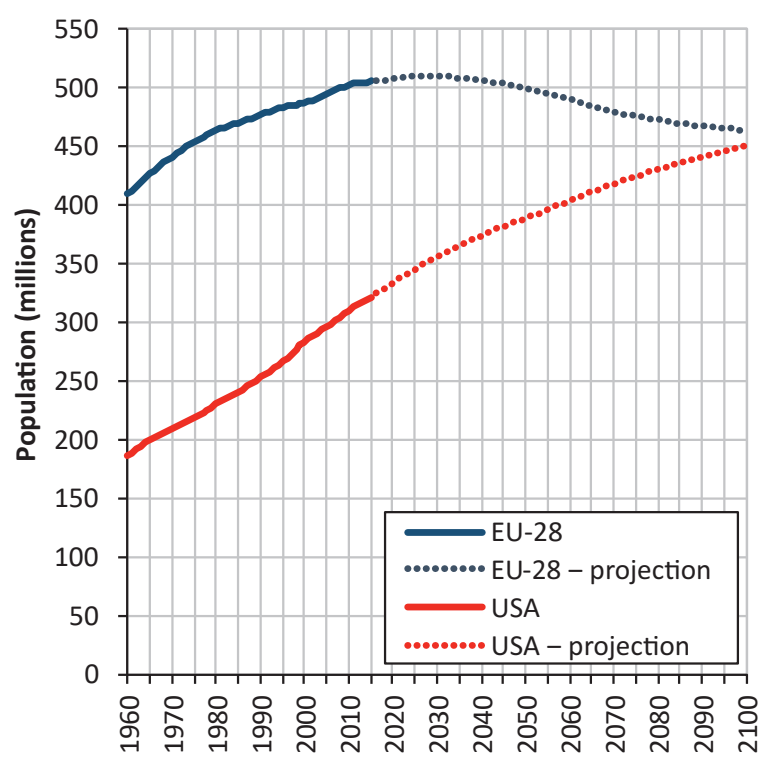

Fig. 1 - Population trends in the EU-28 and in the US, 1960-2100. Source of data: United Nations (2015). The year 2015 is the base year of the projection; medium variant; medium-fertility assumption: convergence toward low fertility - increase in total fertility between 2010-2015 and 2045-2050 from 1.89 to 1.92 children per woman in the US and from 1.60 in average to 1.80 in average in the EU (in 2045-2050 the lowest level of 1.52 was forecasted in Portugal and the highest level of 1.96 in France); normal-mortality assumption: continuous rise in life expectancy based on previous trends; normal migration assumption: constant net migration until 2050 and then gradual decline to 50 per cent by 2100 . 
population dynamics and development in the EU and the US, especially for the slowdown in growth and the expected shrinking of the EU population. We analyze the total population change including natural change and migration. We show the major discrepancies between the rates of natural change and focus specifically on fertility and mortality. We devote particular attention to structural dimensions in differences in fertility and mortality, referring to the demographic behavior of population groups (namely ethnic groups in the US) and regional disparities in demographic performance (especially resulting from political, economic and cultural divisions within Europe). As, up to present, only analyses of partial
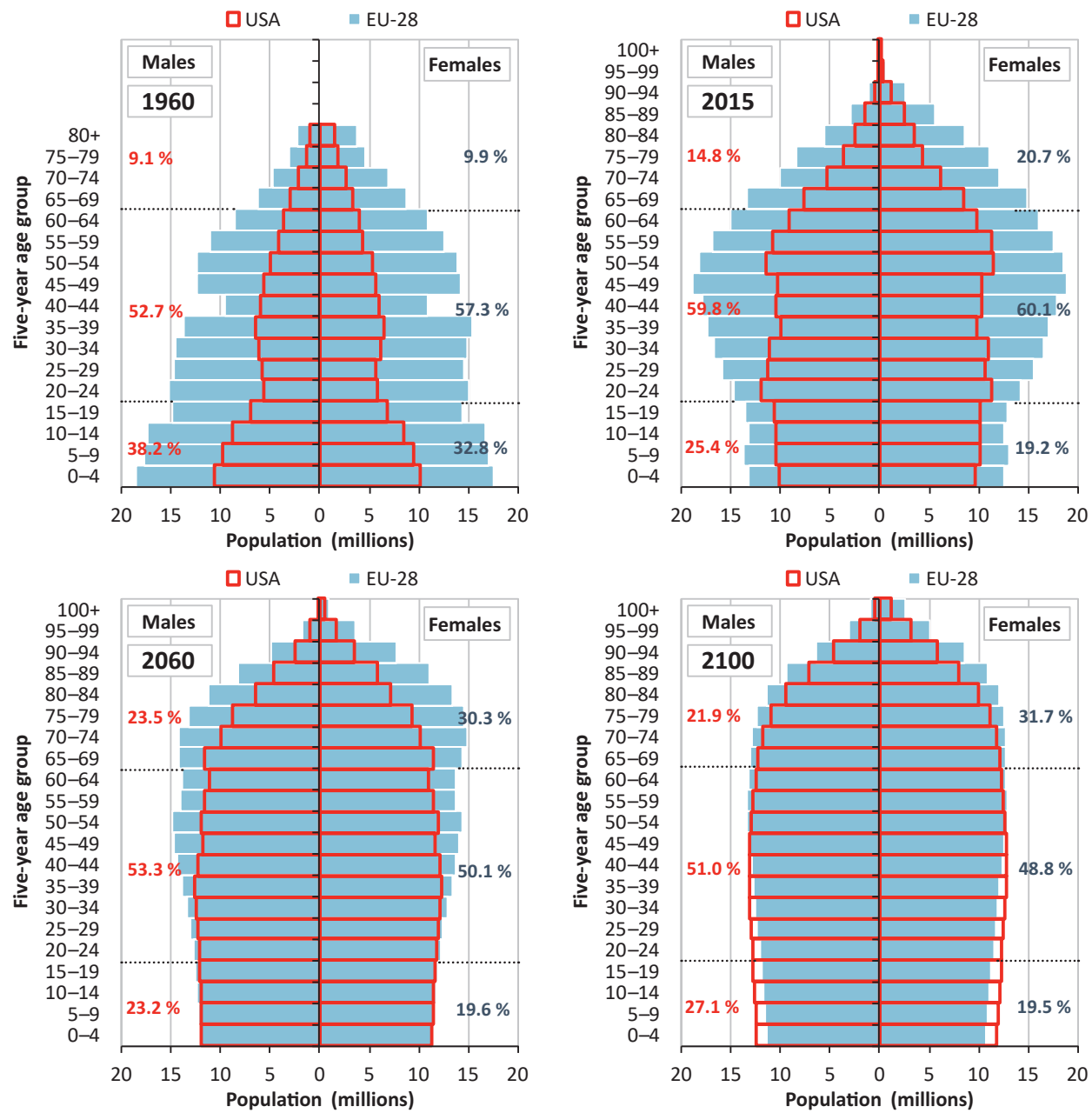

Fig. 2 - Age structure of the EU-28 and the US, 1960, 2015, 2060 and 2100. Source of data: United Nations (2015). 
demographic components have been published, this study fills the gap by providing a comprehensive overview and interpretation of the main differences between these two World macro-regions.

\section{Methods: territories, indicators and data}

This paper investigates the population development in the United States and the European Union between 1960 and 2015. While the US was a stable political and territorial unit throughout the period under investigation, the EU expanded territorially in consecutive stages. However, in order to compare population dynamics, we need to operationalize the EU as a stable territorial entity. Therefore, in this paper, we understand the EU to be an aggregate of the countries which have been EU Member States since 2013 when the EU was lastly enlarged to include Croatia and which we refer to as EU-28 to reflect the 28 Member States. Since we are analyzing trends from 1960, the EU-28 is in fact an artificial construct for most of the period analyzed. This has implications for the way in which the population development is understood, explained and interpreted. While the US was governed by a single federal administration that fostered a common institutional framework and shared value system throughout the whole period, the EU region was split into the capitalist West and communist East until 1990. It was only with the onset of the new millennium that the EU region became more comprehensively institutionally integrated with a shared value system.

Being aware of the internal differentiation in demographic development within the EU, we accept and adopt the standard sub-division of the EU into four geographic regions - the North, the South, the East and the West (Fig. 3). These regional divisions enable us to reflect Europe's geopolitical division in the second half of the $20^{\text {th }}$ century which has influenced fertility and mortality trends and patterns (Avdeev et al. 2011). In the United States, demographic development differs significantly according to ethnicity/race (Barbieri, Ouellette 2012). Therefore, we note differences in the demographic behavior of four ethnic/racial groups: non-Hispanic whites, Hispanics, Blacks, and Asians along with Pacific Islanders. The uneven distribution of these ethnic/racial groups over the territory of the United States (Fig. 4) significantly impacts on the regional differences within the US. Taking into account internal spatial differentiation within the US and the EU, we use the coefficient of variation, also known as relative standard deviation. The statistical relationship between the proportion of a racial group and fertility or mortality indicators across states is measured by Pearson's correlation coefficient.

In analyzing trends in the total population growth, we describe the natural growth (the difference between live births and deaths) and migration growth (the difference between immigrants and emigrants), calculated as crude rates, i.e. per 


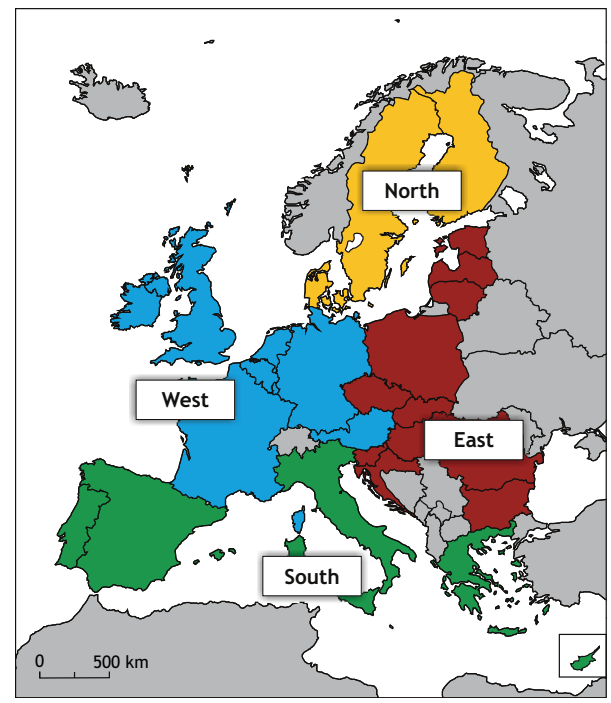

Fig. 3 - EU-28 divided into geographic units
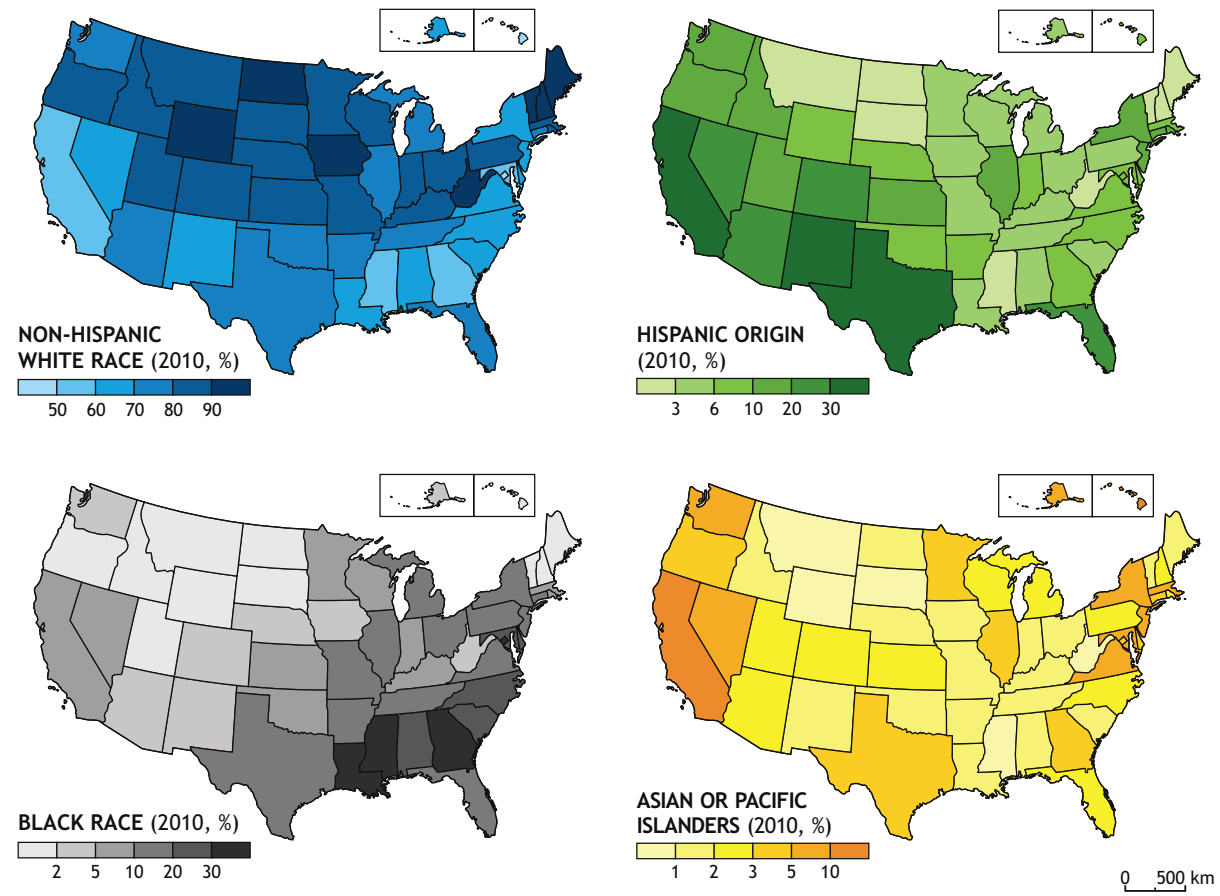

Fig. 4 - Proportion of ethnic groups/races in the US population by states, 2010. Source of data: Population Reference Bureau (2012). 
1,000 mid-year population. In the analysis of fertility, we use the total fertility rate, which is the mean number of children that would be born alive to a woman during her lifetime if she were to bear children according to current age-specific fertility rates and also if she were to survive from birth to the end of her reproductive life. The mortality indicator is represented by life expectancy at birth, which is defined as the average number of years that a newborn person will live if the age-specific mortality rates of the given period are preserved.

The analysis of the natural and migration growth of the EU-28 and the US populations is based on data from World Population Prospects: The 2015 Revision (UN 2015). Data for the analysis of fertility and mortality were taken from Eurostat, INED, and Social Science Research Council databases for the European countries and from the US National Center for Health Statistics for the United States.

The data for European Union Member States is considered to be highly reliable and complete. The data are collected in the individual states by their statistical authorities and compatibility is ensured by Eurostat which consolidates the data using harmonized methodology (Eurostat 2015). The data for the US come from the National Vital Statistics Reports (US National Center for Health Statistics 2017), which do not provide all details. For the individual ethnic/racial groups we used fertility indicators; however, these are not available for the entire period from 1960 - for Blacks since 1964, for Asian or Pacific Islanders and for the group of American Indian, Eskimo and Aleut from 1980, and for the Hispanic population from 1989.

\section{Population change by components $1960-2015$}

In this section, we assess population dynamics and developments in the US and the EU comparing two components of population change, i.e. natural change and net migration between 1960 and 2015. We use data from the World Population Prospects: The 2015 revision (UN 2015) for total population, births and deaths. We first calculated the natural change from the data on births and deaths. Then, by calculating the difference between total population change and natural change, we obtained figures for net migration (this is sometimes referred to as "net migration plus statistical adjustment" as it also includes all changes in the population that cannot be classified as births, deaths, immigration or emigration, see for instance European Commission 2015b).

The comparison shows significant differences in population dynamics between the US and the EU. The rate of natural growth, which is determined by fertility and mortality levels, declined in EU countries throughout the whole period to levels below $1 \%$ annually (i.e. an increase of one person per 1,000 inhabitants). In the US, the drop in the natural growth rate stabilized in the 1980 s and despite 


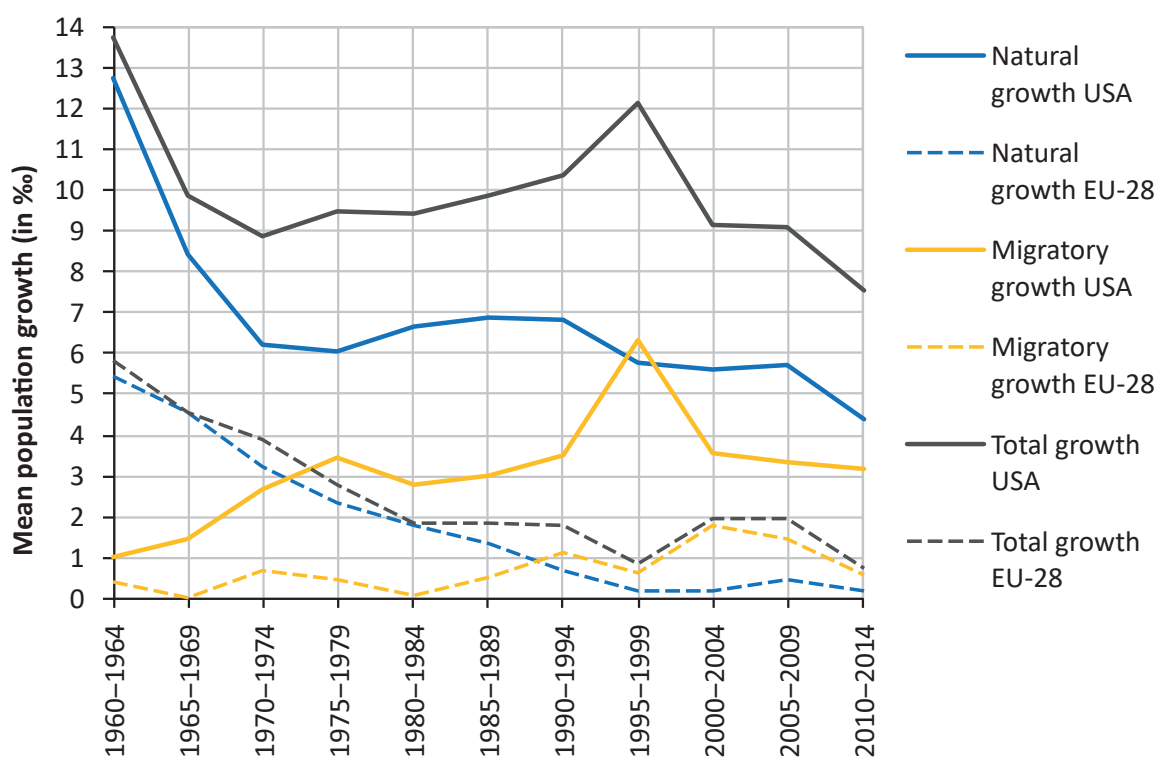

Fig. 5 - Developments in natural, migration and total growth in the EU-28 and in the US. Source of data: United Nations (2015).

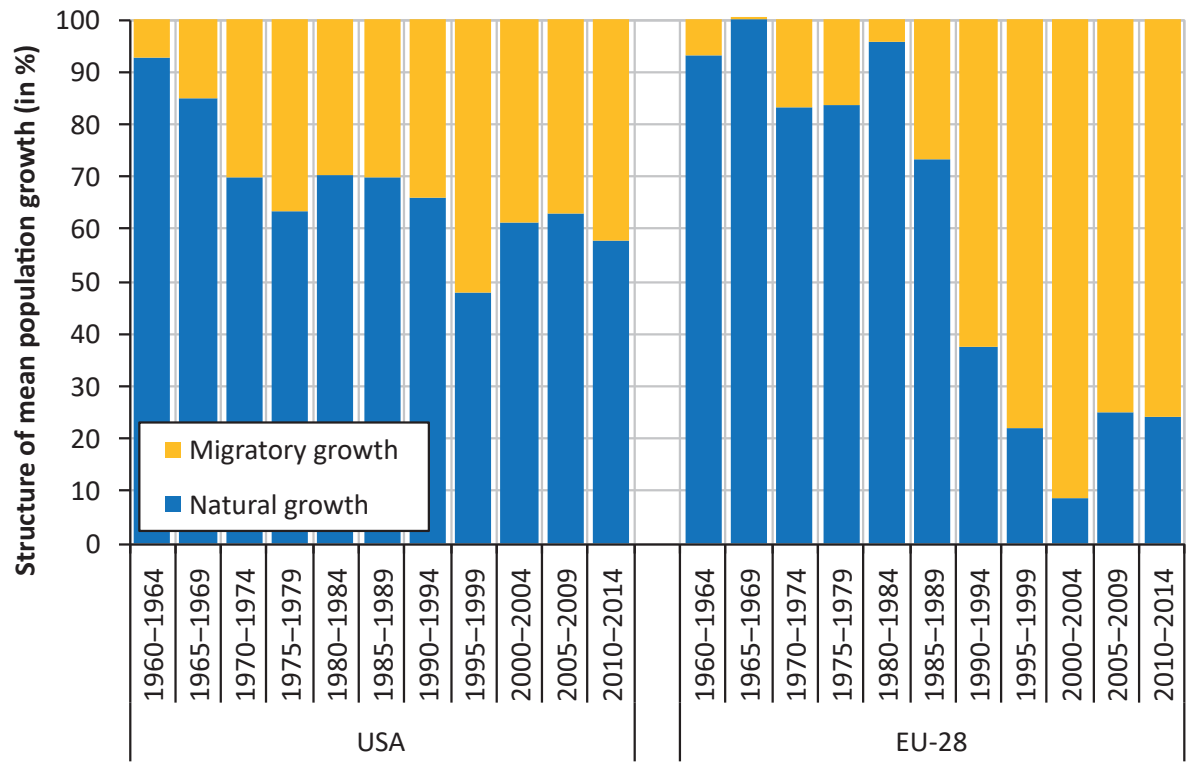

Fig. 6 - Structure of population growth in the EU-28 and the US. Source of data: United Nations (2015). 
a minor decrease since the 1990s it did not fall below $4 \%$ a year. Hence, we can observe a major difference in the effect of the natural increase on the US population compared with the EU countries (Fig. 5).

However, the total population increase was also influenced by migration. While in the US the net migration rate surged from $1 \%$ in the early 1960 s to over $6 \%$ at the late1990s, in the EU it was only around $0.5 \%$ till the late 1980 s and around $1 \%$ in the 1990s (Fig. 5). Immigration to the US occurred among immigrants of Hispanic and Asian origin (Shrestha, Heisler 2011). Only in years after the millennium, the rate of migration in the EU increased to $2 \%$, while in the US stabilized at $3.5 \%$. However, the post 2008 economic recession resulted in the decline in net migration rate in the EU to under $1 \%$, thus again increasing the discrepancy between the EU and the US. Nevertheless, the recent migration of refugees (since 2015) is likely to change this situation dramatically.

The two components contributed to population change in the EU and the US in significantly different ways (Fig. 6). Notwithstanding the significant contribution of migration, US population growth has primarily been driven by natural increases. At present natural increases account for almost $60 \%$ of total population growth; however, this was much higher in the 1980s (about 70\%) and especially in the 1960 s (85-90\%). The EU experienced more radical change in the contribution of natural change and net migration to the overall population growth. While in the 1960 s the average proportion of natural increase in the total population growth reached more than $95 \%$ and was above $70 \%$ until the late 1980 s, the proportion sharply declined to $20 \%$ in the late 1990 s and to below $10 \%$ in $2000-2004$. This change was driven not only by increasing net migration, but especially by a severe decline in the crude rate of natural change. Hence, while US population growth is still fueled by natural increase accompanied with migration, the current population growth in the EU-27 is almost exclusively driven by immigration.

We see this difference in natural growth as the key factor behind the different population dynamics in the two regions. Therefore, in the sections that follow, we will specifically investigate trends in fertility and mortality. We will show how these two components of natural population change contributed to the overall population performance, ascertain which of them is primarily responsible for the difference observed between the US and the EU, and discuss the factors influencing their levels and development over time.

\section{Fertility differentials}

In this section, we focus on the differences in fertility between the EU and the US. Firstly, we illustrate developments between 1960 and 2015 highlighting how demographic behavior and differences in fertility between the populations in the 
two regions began to diverge from the late 1980 s onwards. Then we attempt to ascertain the key factors behind this disparity. While common wisdom often points to structural differences in populations of different ethnicities and religions, we also highlight the impact of regional disparities in demographic behavior, which are produced by a more complex combination of underlying causes and conditions. Finally, we establish which sub-populations are primarily responsible for the recent disparity in the aggregate levels of the total fertility rate (total fertility rate) in the EU and the US.

Since the post-World War Two baby boom was larger in the US, the US total fertility rate in the early 1960s was considerably higher than that in the EU (Fig. 7). Before 1960 total fertility rate had peaked at 3.7 children per woman in the US, whereas in the EU as a whole it did not surpass 3 children per woman. Over the period that followed, a more rapid and profound drop in total fertility rate occurred in the US, where total fertility rate fell to its lowest level of 1.8 in the mid-1970s. In the 1980s a reversal occurred as total fertility rate began to increase gradually towards replacement level. The aggregate picture for the EU shows that total fertility rate began to decline to below replacement level in the mid-1960s. This decline was slower, longer and deeper (Fig. 7). However, there are substantial differences within EU countries. While the timing of the decline in total fertility rate in Western and Northern Europe largely corresponded with that in the US, it was delayed by nearly a decade in Southern Europe and by two decades in Eastern Europe which experienced a much deeper drop in total fertility rate to far below 1.5 from the mid-1990s (Fig. 8).

The initial decline in total fertility rate was associated with the decreasing mean age of the mothers at childbirth (Fig. 7) and determined by modernization, the growing participation of women in the labor market, welfare policies and the societal emphasis placed on the model of the two-child nuclear family. The later stagnation or further decline of total fertility rate to below replacement levels was a result of the increasing mean age of mothers at childbirth and was encouraged by changing values towards a preference for individual self-fulfillment rather than establishing a family which has resulted in the postponement of childbearing, small families and even childlessness (Beets 2011). These developments are referred to as the second demographic transition (Lesthaeghe 2010).

Although trends in changes in the mean age of the mother at childbirth are similar in both macro-regions, the US increase has slowed while it continues to grow in the EU. As the mean age of mothers at childbearing has remained significantly lower in the US than in the EU, there has been less postponement of fertility in the US than in the EU. Accordingly, some of the differences in fertility between the EU and the US are related to the timing of childbearing (Frejka, Westoff 2008).

The difference of 0.5 children per woman between the US and the EU, which appeared in the late 1980s and remained for two decades (Fig. 7), was the key 


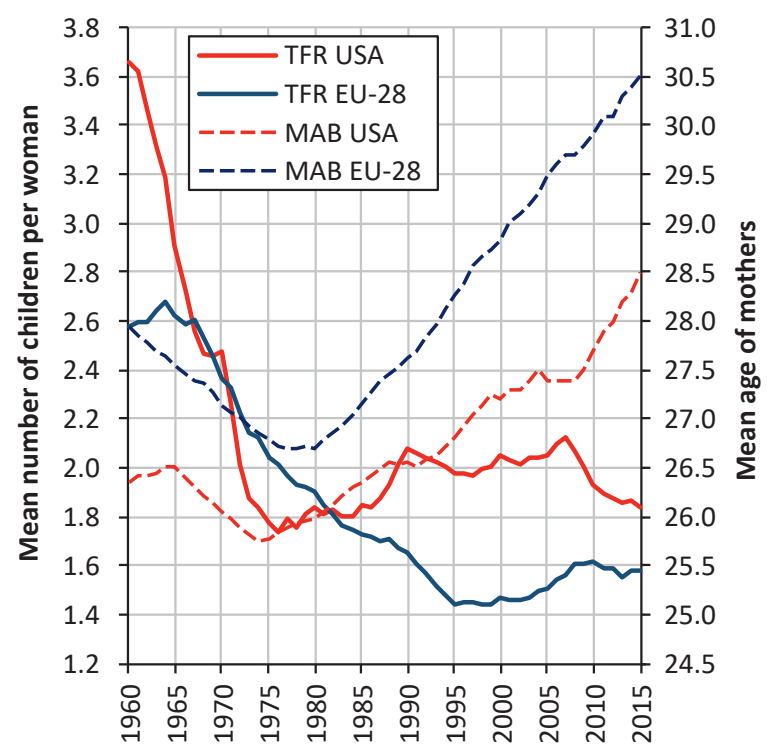

Fig. 7 - Trends in total fertility rate and mean age of mothers at childbirth in the EU-28 and in the US, 1960-2015. Source of data: US National Center for Health Statistics (2017); INED (2013); Eurostat (2015).

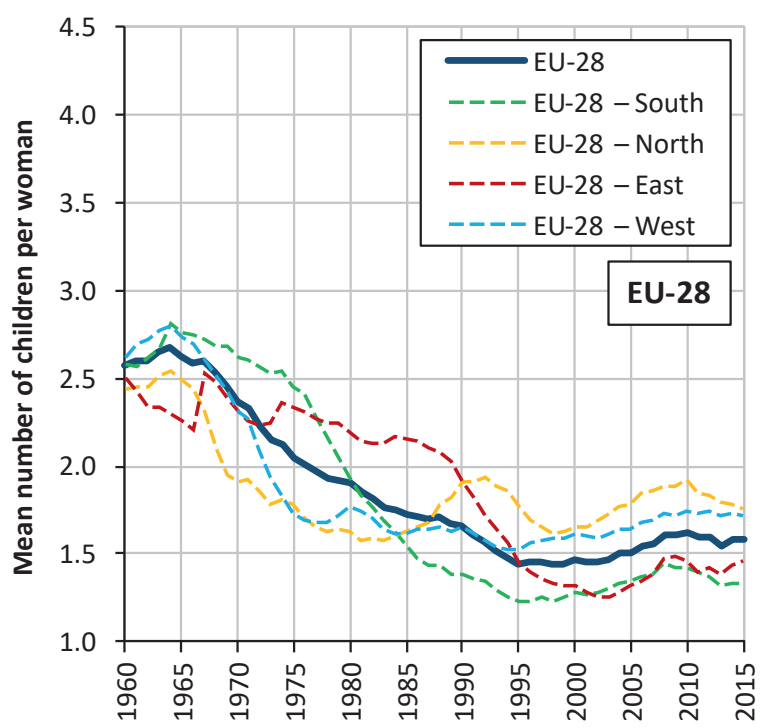

Fig. 8 - Trends in total fertility rates in the EU-28 by regions, 1960-2015. Source of data: Eurostat (2015). 
factor behind the higher natural population growth in the US. But how can we explain this difference? The EU decline in total fertility rate to sub-replacement fertility levels is seen as the result of the second demographic transition, and the different paths of fertility change among the EU regions can be explained by the different timing of the onset of the second demographic transition in Northwestern, Southern and Eastern Europe (Sobotka 2008; Polesnám Kocourková 2016). However, the return to and stabilization of replacement level fertility in the US population (Kane 2013) lies in contradistinction to the common view that sustained sub-replacement fertility is one of the main characteristics of the second demographic transition (Lesthaeghe 2010). Fertility at replacement level has been called "American demographic exceptionalism" (Morgan 2003) and has raised doubts as to whether the second demographic transition is relevant to analyzes of the US population (Lesthaeghe, Neidert 2006). Lesthaeghe (2010) has pointed out that the population in the US is heterogeneous and that there are sub-populations with total fertility rate well above the replacement level indicating that they have not yet completed their first demographic transition.

This leads us to look more closely at the total fertility rate of individual ethnic groups in the US and their contribution to the overall fertility. The substantially higher fertility of Hispanic women, which remained consistently above 2.7 between 1990 and 2008, suggests that the influx of the Hispanic population since the 1980s has been responsible for the increase in total fertility rate in the US. However, the proportion of the Hispanic population was low (9\% in 1990) for it to have significantly altered total fertility rate. While it is true that the proportion of the Hispanic population increased to $16 \%$ in 2010 , it compensated for the fall in the fertility of Asians and Pacific Islanders beginning in the late 1980s (Sutton, Mathews 2004), rather than changing the course of total fertility rate for the total US population.

The development of total fertility rate in the US has markedly corresponded with the fertility rate of the white non-Hispanic population (Fig. 9). Importantly, the fertility rate of non-Hispanic Whites in the US tends to be higher than the fertility rates of their counterparts in Europe (Morgan 2003). As the white non-Hispanic population still accounts for over $70 \%$ of US population, and the differences between the other ethnic groups compensate one another rather than changing the general course set by the white majority, we shall examine the factors behind the higher level of fertility among the white non-Hispanic US population compared with Europe. It is partly explained by the higher degree of religious faith and associated religious practices and the greater influence of religious values on family and reproductive behavior in the US population (Frejka, Westoff 2008).

However, the behavior of the white non-Hispanic US population is far from uniform. There are significant regional differences in total fertility rate within the US (Fig. 10). While these differences were related to the racial/ethnic composition 


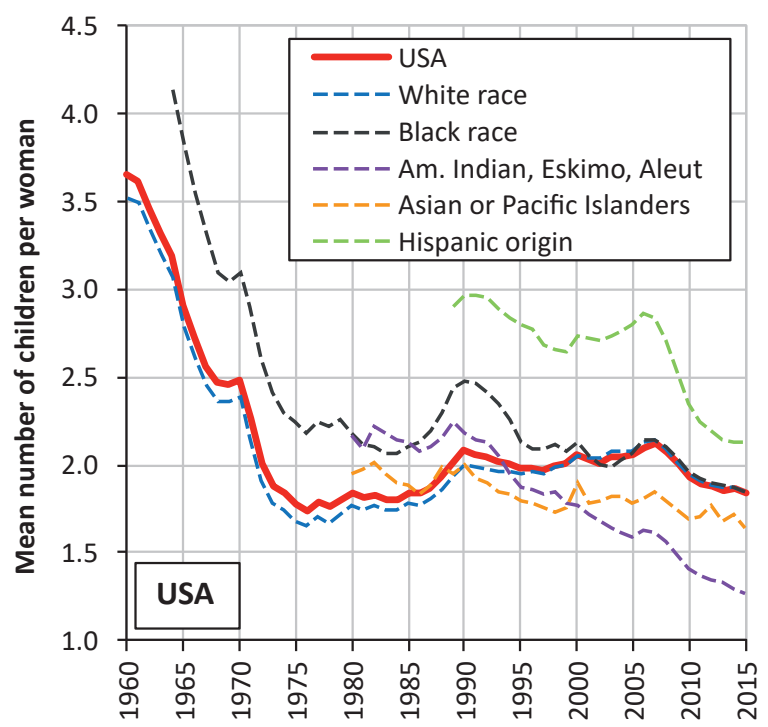

Fig. 9 - Trends in total fertility rates in the US by racial/ethnic groups of population, 1960-2015. Source of data: US National Center for Health Statistics (2017).

in different states, the correspondence between high proportions of Hispanic and high fertility states observed in 1990s (Pearson's correlation coefficient close to 0.5) had almost vanished by 2015 (Pearson's correlation coefficient around 0.15) with Utah and South Dakota showing the highest total fertility rate, which cannot be explained by regional ethnic differentiation. In 1990 and 2015, the maximum total fertility rate was recorded in the state of Utah, which has a considerable proportion of distinctive religious groups, such as the Mormons. A decline in total fertility rate has been recorded in states with large proportions of Hispanics and Asians, such as California, and in the southern states with a larger share of Afro-Americans. The lowest levels of a total fertility rate of below 1.6 have been recorded in the NorthEast which iseven lower than that in Northern and Western Europe. Lesthaeghe and Neidert (2006) described this picture of regional differentiation as "American bipolarity", which they consider to be more of an apt description than "American exceptionalism". Thus, besides the sections of the US population that confirm the uniqueness of the American fertility pattern, there is an important segment of the non-Hispanic white population in both Eastern and Western parts of the USA which clearly displays signs of the second demographic transition and bridges the gap suggested by the comparison of the aggregate figures for the US and the EU.

The region consisting of EU countries exhibits much larger regional differences in total fertility rate over time and currently than can be observed in the US (Fig. 10). In the 1960s, socialist Eastern Europe recorded lower levels of fertility 


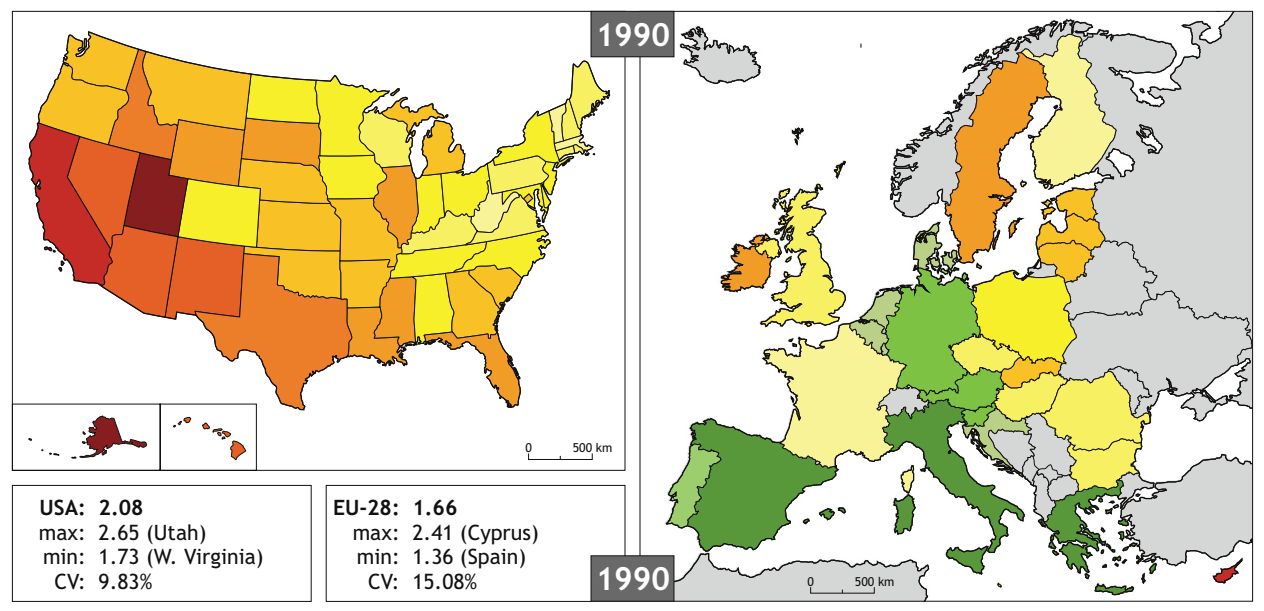

\section{TOTAL FERTILITY RATE}

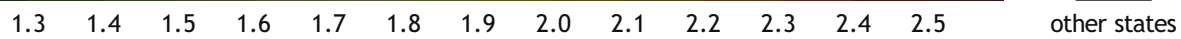

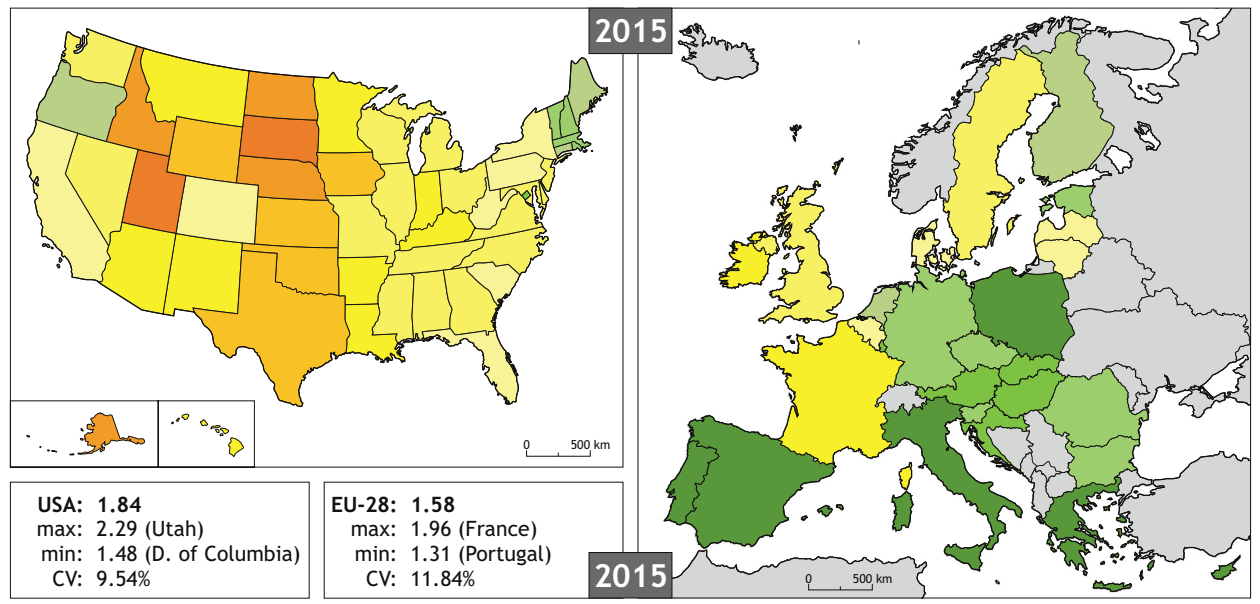

Fig. 10 - Regional differentiation of total fertility rate in the US and EU-28 in 1990 and 2015. Source of data: US National Center for Health Statistics (2017); INED (2013); Eurostat (2017). 
than other countries which were affected by a lingering post-war baby boom (Fig. 8). The 1970s saw a sharp decline in fertility in Northern and Western Europe: a clear sign of the onset of the second demographic transition. The later fall in total fertility rate in Southern Europe and especially the relatively higher levels sustained in Eastern Europe contributed to the increasing heterogeneity within a region divided by the Iron Curtain until the 1990 (Fig. 10). Although the total fertility rate decline in Southern Europe and, later in Eastern Europe, followed the course set earlier by western countries, its rapid, deep fall and convergence below the replacement level and far below the levels in Northern and Western Europe contributed to a new set of regional disparities between Northwestern and Southeastern Europe (Frejka, Sobotka 2008, Avdeev et al. 2011).

Unlike the US, in which the higher fertility in some states can be associated with the higher occurrence of Hispanic and/or deeply religious populations, regional differences in the fertility level in the EU must be down to other factors. In the past 25 years, higher total fertility rates have not been recorded in many of the countries with the highest proportion of religious populations, such as Italy, Greece and Portugal, but in Northern and Western European countries that are the least religious, such as Sweden, Denmark, Finland, France and Belgium. This suggests that other factors are decisive in childbearing (Frejka, Westoff 2008). These latter countries are known to have the most advanced family policies that harmonize work and family, and also promote gender equality. However, these types of pro-family policies are not found to the same extent in Southern Europe nor, since the fall of Communism, in Eastern Europe, where, notwithstanding value changes associated with the second demographic transition, the decline in total fertility rate has been further strengthened by socio-economic hardship.

While Kane (2013) suggests that "American bipolarity" distinguishes the US from Europe, the disparities in total fertility rate measured by the coefficient of variation are much higher between EU states than they are across the US (11.8\% and $9.5 \%$ in 2015 respectively, see Fig. 10). When compared with the US, the EU north-west/south-east divide shows similar levels of total fertility rate in the Northwest as in large parts of the United States, while Southern and Eastern Europe remain distinct. Thus the primary issue for policy concerns is population development and in particular fertility levels in this part of the Europe.

\section{Mortality differentials}

In this section we explore the differences in mortality between the EU and the US. Firstly, we look at the development of life expectancy at birth between 1960 and 2015 and point out the slower progress and even stagnation in the US, which lost its favorable position to the European Union. Then we consider the internal 


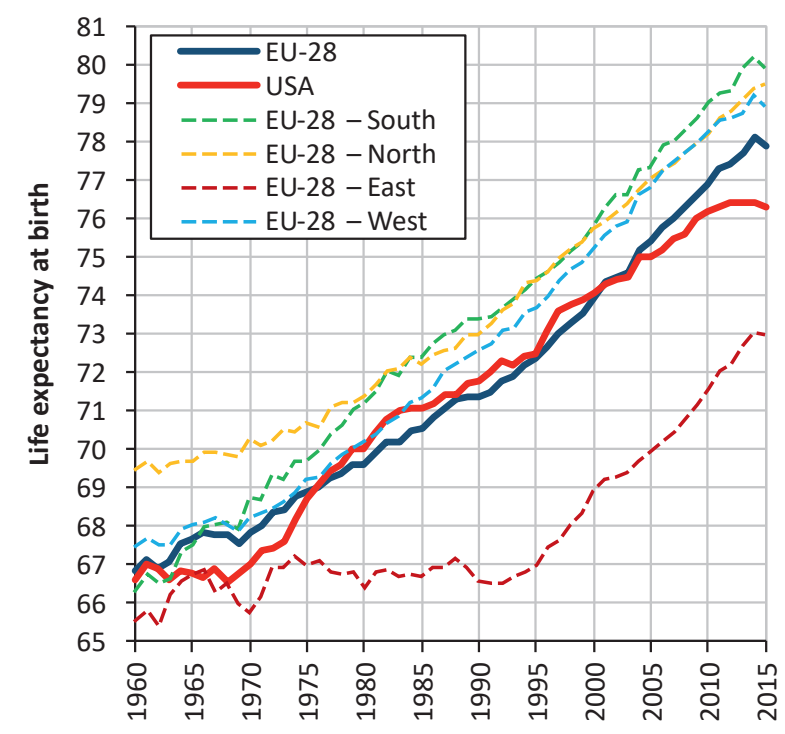

Fig. 11 - Life expectancy at birth, the US and the EU-28, 1960-2015, males. Source: US National Center for Health Statistics (2017); Eurostat (2015).

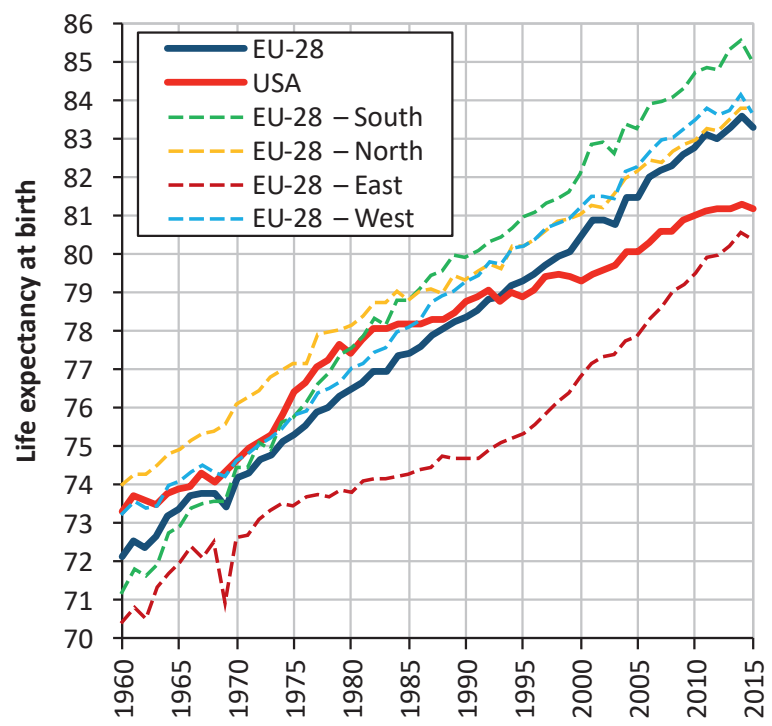

Fig. 12 - Life expectancy at birth, the US and the EU-28, 1960-2015, females. Source: US National Center for Health Statistics (2017); Eurostat (2015). 
differentiation within the EU countries and illustrate the distinction between Eastern Europe and the rest of the EU. While aggregate development in the EU was affected by stagnation and less progressive trends in male and female mortality in communist Eastern Europe throughout the 1970s and 1980s the trend was reversed from the 1990s on. During the same period, the US performance declined. Therefore, we attempt to ascertain the key factors behind the slower progress in the US when compared with the steady improvement in life expectancy in the EU.

While the US population was more dynamic as regards fertility, it performed less well on mortality. Both macro-regions made remarkable progress in terms of life expectancy at birth from the 1960s on (Fig. 11 and Fig. 12), but from 1980 life expectancy at birth increased more rapidly in the EU (Glei, Meslé. Vallin 2011). While increases in male life expectancy at birth followed a more or less similar trend in the US and EU until 2010 (Fig. 11), growing differences in female life expectancy at birth (Fig. 12) attributed to the US slowdown. By 2015, female life expectancy at birth had reached 83 years in the EU while in the US it was only 81 years. The development that occurred over the three decades from 1980-2010 reversed the previous trends for women. The gains were substantially more rapid in the EU countries, which achieved a gain of 6.5 years compared to only 3.5 years in the US.

However, the general picture for EU countries needs to be deconstructed. While Western, Northern and Southern Europe experienced a continual growth in life expectancy at birth for both sexes, in Eastern Europe male life expectancy stagnated from the 1970s to the 1990s and females experienced a deceleration in growth during the same period (Fig. 11 and Fig. 12). Hence in terms of life expectancy at birth, countries in Western, Northern and Southern Europe performed better than the US, while the lower aggregate figure for the EU was affected by developments in Eastern Europe.

The differing development of mortality within the EU region reflected Europe's post-World War Two geopolitical division between capitalist West and communist East (Hulíková Tesárková, Kašpar, Zimmermann 2015; Rychtař́ková 2015). While progress in combating cardiovascular diseases through medical innovation and behavioral changes (healthier lifestyles and diets) had an impact on mortality in Northern, Western and Southern Europe since the beginning of the 1970s, the poor improvement in Eastern Europe reflected slow progress in fighting cardiovascular disease and the growth in "lifestyle diseases" like smoking, alcoholism and an unhealthy diet especially related to self-destructive behavior of man in primary and secondary sector occupations (Carlson, Hoffmann 2011 call this the state socialist mortality syndrome). Serious environmental pollution presented another risk factor responsible for the deterioration in the health status of the population of Eastern Europe. According to Meslé and Vallin (2002), Eastern Europe faced a health crisis as cardiovascular mortality stagnated or even increased until the 
beginning of the 1990s. The health systems in Eastern Europe were not able to adjust to the changing health needs of the population.

In the mid-1990s, the disparity in life expectancy at birth between Eastern Europe and the rest of EU ceased growing; however, the gap that had formed during the preceding two decades remained as it was. The main reason life expectancy in Eastern Europe lagged behind the rest of EU is the higher cardiovascular mortality. Consequently, the difference between the East and the other three regions of the EU continued to be significant until 2015, when men in the East lived 7 years fewer than those in the South and women in the East lived 5 years fewer than those in the South (Fig. 11 and Fig. 12). This east-west divide, which was not overcome in 1990-2015 (Fig. 13 and Fig. 14) is expected to persist in the coming decade (Avdeev et al. 2011).

The slower increase and stagnation in life expectancy in the US compared to the $\mathrm{EU}$ is related to the lifestyle differences affecting the population's health and access to health care. In the US, these are strongly related to social/racial inequalities (National Research Council 2011). By comparison, the population in EU countries has universal access to health care that helps to eliminate health inequities and inequalities.

Obesity and smoking are life styles which are seen to be responsible for the slower progress on mortality levels in the US. The prevalence of obesity in the US is higher compared with similarly advanced countries, and in particular, among women (Alley, Lloyd Shardell 2010; Pison 2008). As one might expect, it is more frequent among the poorest sections of the US population (Pison 2008). Steptoe and Wikman (2010) also point to the impact of low physical activity among the elderly as another factor behind the growing difference between life expectancy in the US and other advanced countries. Another important factor with a negative impact on mortality trends in the US is smoking (Pampel 2010). Fifty years ago, Americans smoked more frequently than Europeans. The divergence in the trajectories of women's life expectancies at birth between the US and the EU in the 1980s and 1990s is thus related to the differential impact of smoking-related mortality on female populations at a later age (Staetsky 2009). According to Preston, Glei, Wilmoth (2011), mortality will continue to be influenced by former levels of smoking for another two decades; however, the impact will decline (National Research Council 2011). Nevertheless, Stewart, Cutler, Rosen (2009) argue that the improvement in life expectancy due to the weakening impact of smoking is outweighed by the increasing negative impact of obesity and associated health problems.

These health problems are further compounded by inequality in access to health care in the US associated with the lack of compulsory health insurance. Although the US is considered to be a global leader in technological and medical innovations, not all of its inhabitants enjoy these equally. About $16 \%$ of the US population does 
not have health insurance, seriously limiting their access to health care (Pison 2008). The lack of universal health care and compulsory health insurance are thus highlighted as featuring among the key factors behind the stagnation in life expectancy in the US (National Research Council 2011).

US mortality is partly affected by racial and income inequalities. This concerns Afro-Americans especially. In 2007, the life expectancy of men and women reporting their race as Black was shorter than that of Whites by 6 and 4 years respectively (Arias 2011). The lower levels are associated with higher poverty rates, exposure to violence and crime, other disadvantages in segregated localities (Geronimus et al.1996), higher mortality linked to HIV/AIDS and to homicides among Black men (Harper et al. 2007).

Differences in the mortality differentials for ethnicities are reflected in the geographic disparities across the US, where the lowest life expectancy at birth in 1990 and 2015 was found in Southeastern US states (excluding Florida) that typically have the highest proportion of Afro-Americans. The correspondence between the spatial patterns of life expectancy and the proportion of Afro-Americans was strong despite having declined between 1990 (Pearson's correlation coefficient -0.90 for males and -0.84 for females) and 2015 (Pearson's correlation coefficient -0.68 for males and -0.59 for females). While the geographic disparities in life expectancy between 1990 and 2015 decreased for males and increased for females, the variation was lower for the female population (Fig. 14). While the situation regarding males can be related to a decrease in disparity between non-Hispanic white and Afro-American males due to lower levels of crime, in the case of the women, the growing disparity can be explained by the higher negative health effects of obesity among Afro-American females.

In contrast to fertility, geographic disparities in mortality between the EU and US states are significantly lower. However, as in the case of fertility, the degree of spatial variability in life expectancy was higher in the EU than in the US for both sexes (Fig. 13 and Fig. 14). While in the US the regional differences in mortality are primarily a result of the differences in the ethnic composition of states, especially with regard to the Afro-American population, in the EU the primary regional division between Eastern Europe and the rest of $\mathrm{EU}$ is a consequence of path dependency rooted in the decades of communism and its effect on the health of the population in Eastern Europe.

\section{Conclusions: the challenge of anticipated demographic development}

In this paper we have analyzed population changes in the EU and the US, focusing specifically on components which are primarily responsible for the recent differences in the population dynamics of these two world macro-regions and which 


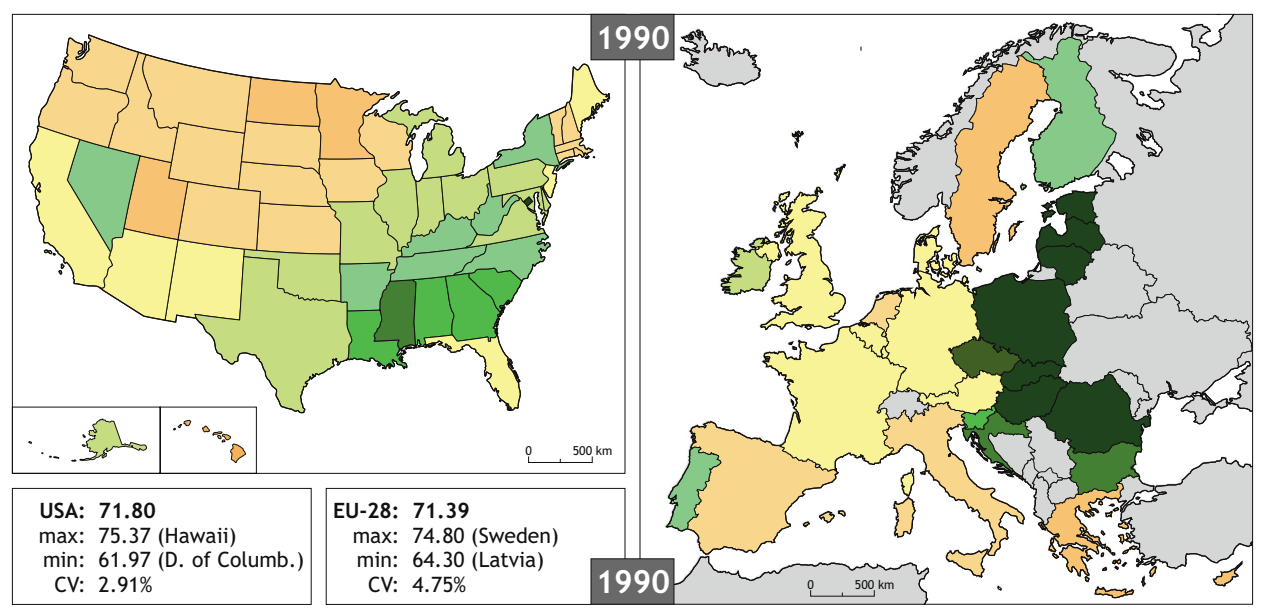

\section{LIFE EXPECTANCY AT BIRTH, MALES}

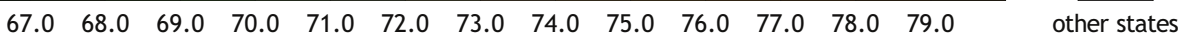

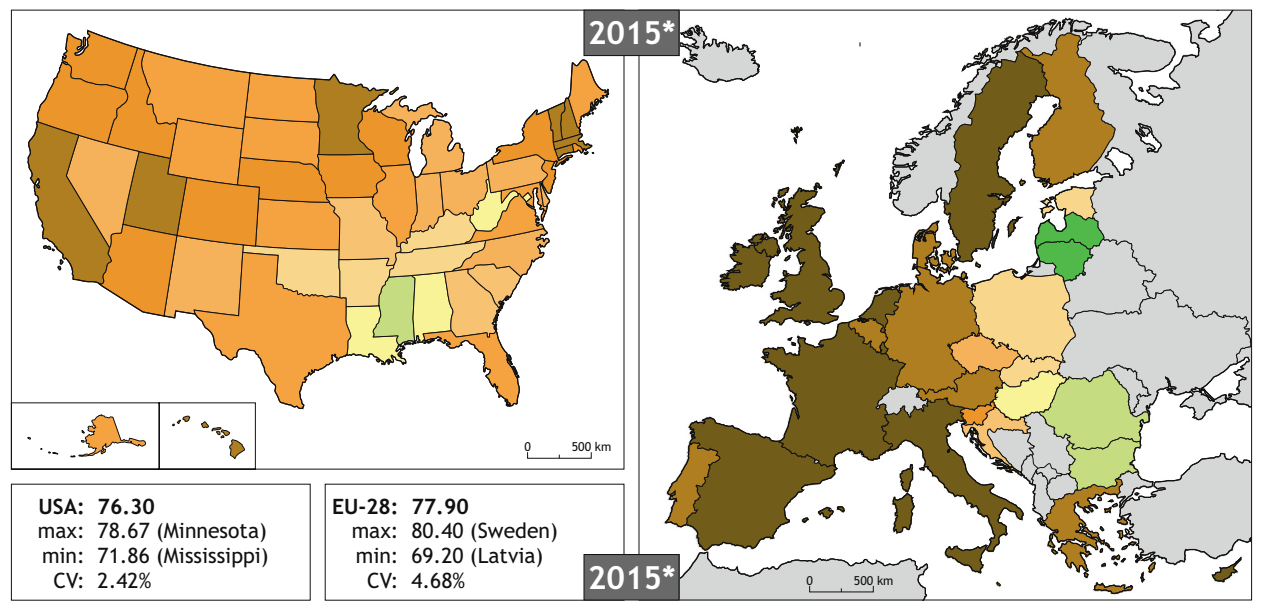

Fig. 13 - Regional differentiation of life expectancy at birth in the US and in the EU-28 in 1990 and 2015, males. * US data are for the period 2013-2014. Source: US National Center for Health Statistics (2017); INED (2013); Eurostat (2017); Social Science Research Council (2017). 


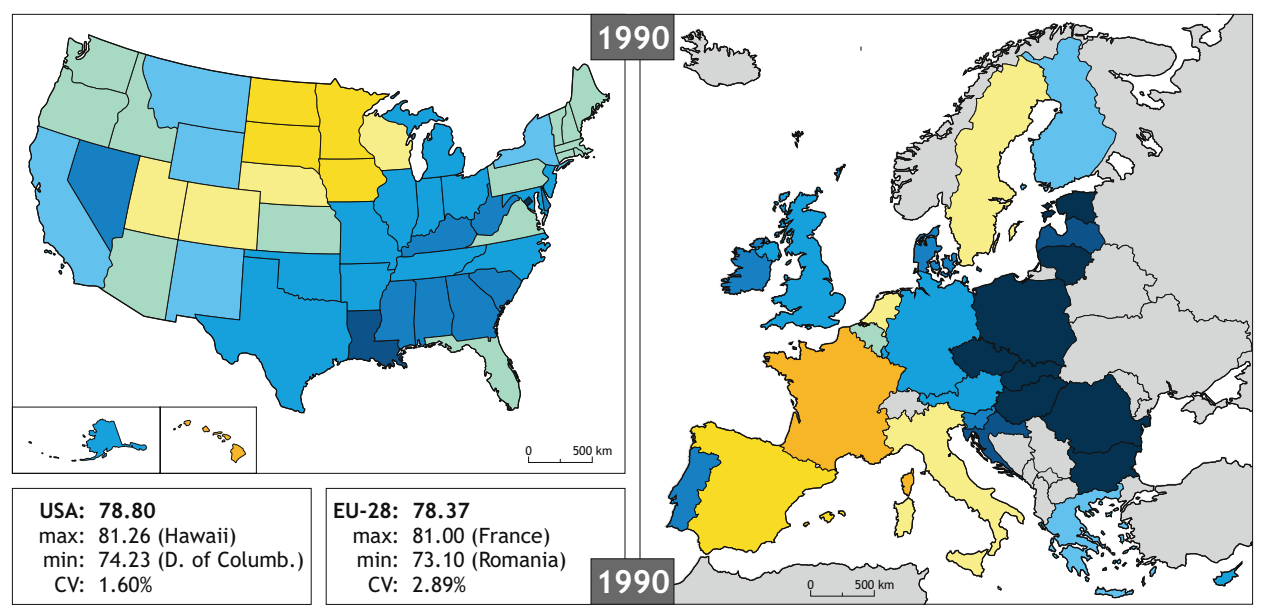

\section{LIFE EXPECTANCY AT BIRTH, FEMALES}

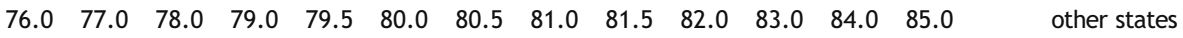

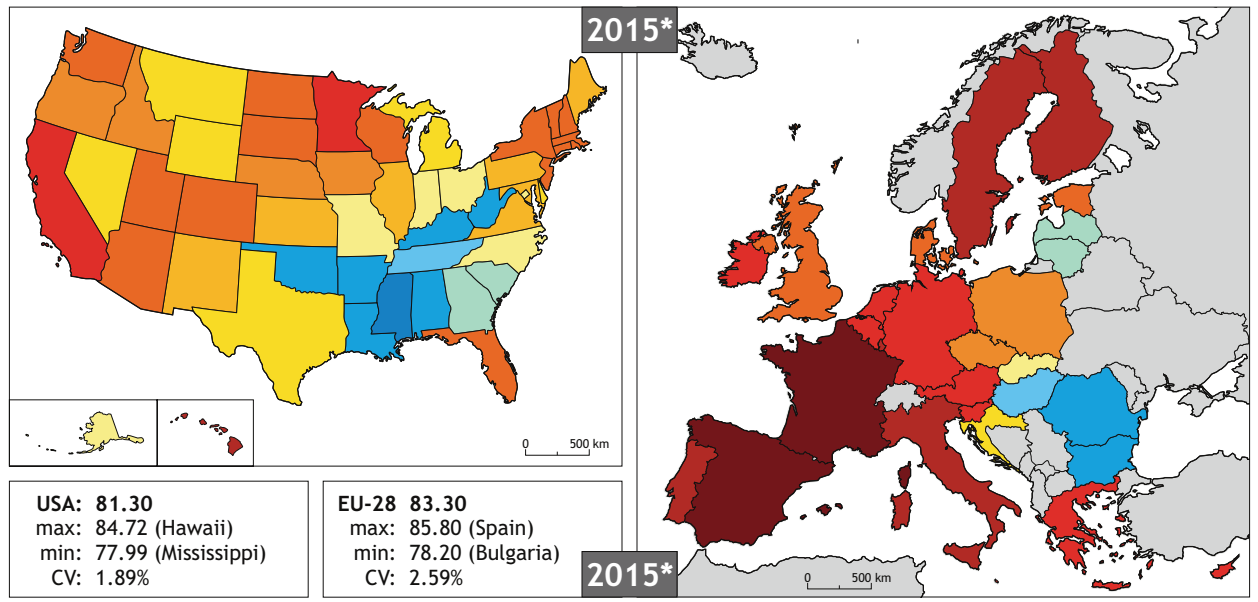

Fig. 14 - Regional differentiation of life expectancy at birth in the US and in the EU-28 in 1990 and 2015, females. * US data are for the period 2013-2014. Source: US National Center for Health Statistics (2017); INED (2013); Eurostat (2017); Social Science Research Council (2017). 
are likely to influence future population growth and structure (UN 2015). Despite having followed similar population behavior trajectories over the last 50 years, the two regions have seen increasing disparities in the character of natural change and converging levels of immigration in recent decades. The largest differences between the EU and the US can be observed in the level and structure of fertility. The average number of births per woman among the EU population is currently about 0.3 lower than in the US where women give birth 2.5 years earlier than women in the EU. Mortality trends are characterized by increases in life expectancy at birth for both sexes and both regions, while in recent years a faster rate of growth has been reported in the EU population.

The below reproduction levels of fertility in the EU, especially in the East and South, slowed population growth in the region. The effects of this will be seen over the coming decades and will lead to the population shrinking due to the negative population momentum. Moreover, according to UN projection, total fertility in some countries in the Eastern and Southern Europe (Poland, Portugal and Greece) will not increase over 1.6 by 2050 (UN 2015). As future population growth is highly dependent on the path that future fertility will take, increasing life expectancy at birth cannot compensate for the overall population loss. While migration is hard to forecast, it opens up a window of opportunity for Europe in terms of total population growth and, since immigrants are on average younger than the resident population (European Commission 2015b), this is especially true in term of changes in the age structure and potential for adjustments in fertility levels that could slow down or even reverse the forecasted development.

While long-standing immigration to the US has had an impact on current demographic behavior and future trends, the non-Hispanic white population in some US regions has maintained higher levels of fertility than seen in the EU today. Consequently, the population growth of the US is still driven more by natural change than migration, despite immigration being significantly high and steadily increasing.

The differing population dynamics will continue to affect population development in the two macro-regions for the remainder of this century. The recently growing gap in population dynamics will paradoxically lead to the closing of the gap in the total population size as forecasted for 2100 (UN 2015; see Fig. 1). In the meantime, we can ask whether the shrinking population is acceptable to the EU and its Member States. While population policies number among the competencies of national governments, over recent decades we have seen the growing impact of values associated with the spread of a capitalist consumer society on different paths and outcomes associated with the second demographic transition in EU regions (Sobotka 2008). The neoliberal articulation of capitalist values throughout post-communist countries has resulted in greater promotion of individualism while welfare state provision and support for family formation have been 
undermined (Frejka 2008; Kahlert, Ernst, eds. 2010). The potential for mitigating the EU negative trend thus lies in ways of influencing the very low fertility levels in South and Eastern Europe.

While the EU institutional framework and value systems still reflect pathdependencies from the era when Europe was divided, the US has had decades of a shared nation-wide administration and value system. Yet, as the demographic developments have shown, the US is not without deficiencies, especially regarding the future effects of the legacies of racial and income inequalities. Nevertheless, we can assume further institutional integration and value cohesion in Europe as well as successful developments in contesting social inequalities in US, which will likely impact convergence in the population dynamics of the two regions. At the same time, the population structure will highlight the $20^{\text {th }}$ century developments reflected in more regressive and thus for future development less favorable age pyramid of the EU population. However, unexpected and volatile international migration may redraw these population projections which were constructed on the basis of assumptions that do not account for the third demographic transition (Coleman 2006).

\section{References}

ALLEY, D.E., LLOYD, J., SHARDELL, M. (2011): Can Obesity Account for Cross-National Differences in Life Expectancy Trends? In: National Research Council (ed.): International Differences in Mortality at Older Ages: Dimensions and Sources. NRC, Washington, DC, 164-192.

ARIAS, E. (2011): United States life tables, 2007. In: National Vital Statistics Reports 59, 9, National Center for Health Statistics.

AVDEEV, A., EREMENKO, T., FESTY, P., GAYMU, J., LE BOUTEILLEC, N., SPRINGER, S. (2011): Populations and demographic trends of European countries, 1980-2010. Population-E, 66, 1, 9-130.

BARBIERI, M., OUELLETTE, N. (2012): The demography of Canada and the United States from the 1980 s to the 2000s. A summary of changes and statistical assessment. Population-E, 67, $2,177-280$.

BEETS, G.A. (2011): A contemporary issue in demography. The rising age at first birth, pros and cons. AUC Geographica, 46, 1, 5-14.

CARLSON, E., HOFFMANN, R. (2011): The state socialist mortality syndrome. Population Research and Policy Review, 30, 355-379.

CINCOTTA, R.P., ENGELMAN, R. (1997): Economics and Rapid Change: The Influence of Population Growth. Occasional Paper 3, Population Action International, 1997, http://pai. org/wp-content/uploads/2012/01/Economics_and_Rapid_Change_PDF.pdf (26.7.2015).

COLEMAN, D. (2006): Immigration and ethnic change in low-fertility countries: A third demographic transition. Population and Development Review, 32, 3, 401-446.

European Commission (2015a): The 2015 Ageing Report. Economic and budgetary projections for the 28 EU Member States (2013-2060). European Economy 3/2015. Publications Office of the European Union, Luxembourg. 
European Commission (2015b): Demography Report. Publications Office of the European Union, Luxembourg.

Eurostat (2015): What we do - Comparing apples with apples. Eurostat, http://ec.europa.eu/ eurostat/about/overview/what-we-do (6.8.2015).

Eurostat (2017): Eurostat database. Population and social conditions, http://epp.eurostat. ec.europa.eu/ (21. 5. 2017).

FOTAKIS, C., PESCHNER, J. (2015): Demographic change, human resources constraints and economic growth - The EU challenge compared to other global players, European Commission (DG EMPL) Working Paper 1/2015, http://ec.europa.eu/social/main.jsp?catId=738\&langId=e n\&pubId=7750\&furtherPubs=yes (2.9.2015).

FREJKA, T. (2008): Determinants of family formation and childbearing during the societal transition in Central and Eastern Europe. In Frejka, T., Sobotka, T., Hoem J. M., Toulemon, L. (eds): Childbearing trends and policies in Europe. Demographic Research, Special Collection 7, 19, 139-170.

FREJKA, T., SOBOTKA, T. (2008): Fertility in Europe: Diverse, delayed and below replacement. In: Frejka, T., Sobotka, T., Hoem, J. M. and Toulemon, L. (eds): Childbearing trends and policies in Europe. Demographic Research 7, 19, 15-46.

FREJKA, T., WESTOFF, C.F. (2008): Religion, religiousness and fertility in the U.S. and in Europe. European Journal of Population, 24, 5-31.

GERONIMUS, A.T. et al. (1996): Excess Mortality among Blacks and Whites in the United States. New England Journal of Medicine, 335, 1552-1558.

GLEI, D.A., MESLÉ, F., VALLIN, J. (2010): Diverging Trends in Life Expectancy at Age 50: A Look at Causes of Death. In: National Research Council (US) Panel on Understanding Divergent Trends in Longevity in High-Income Countries; Crimmins E.M., Preston S.H., Cohen B. (eds): International Differences in Mortality at Older Ages: Dimensions and Sources. Washington (DC), 17-67.

HARPER, S., LYNCH, J., BURRIS, S., DAVEY-SMITH, G. (2007): Trends in the black-white life expectancy gap in the United States, 1983-2003. Journal of the American Medical Association, 297, 11, 1224-1232.

HULÍKOVÁ TESÁRKOVÁ, K., KAŠPAR, D., ZIMMERMANN, P. (2015): Convergent and divergent trends in the European mortality: What is the position of Czechia? Geografie, 120, 1, 26-49.

INED (2013): All about population. Database, http://www.ined.fr (20.9. 2013).

KAHLERT, H., ERNST, W., eds. (2010): Reframing Demographic Change in Europe: Perspectives on Gender and Welfare State Transformations. Lit verlag, Berlin.

KANE, J.B. (2013): A closer look at the second demographic transition in the US: Evidence of bidirectionality from a cohort perspective (1982-2006). Population Research and Policy Review, 32, 47-80.

LESTHAEGHE, R. (2010): The Unfolding Story of the Second Demographic Transition. Population and Development Review, 36, 2, 211-251.

LESTHAEGHE, R., NEIDERT, L. (2006): The second demographic transition in the United States: Exception or textbook example? Population and Development Review, 32, 4, 669-698.

MESLÉ, F., VALLIN, J. (2002): Mortality in Europe: the divergence between east and west. Population-E, 57, 1, 157-198.

MORGAN, S.P. (2003): Is low fertility a twenty-first-century demographic crisis? Demography, 40, 4, 589-603.

National Research Council (2011): Health in International Perspective: Shorter Lives, Poorer Health. In: Woolf S. H., Aron L. (eds): Panel on Understanding Cross-National Health Differences among High-Income Countries. Washington, DC. 
PAMPEL, F.C. (2011): Divergent Patterns of Smoking across High- Income Nations. In: National Research Council (ed.): International Differences in Mortality at Older Ages: Dimensions and Sources. Washington, DC, 132-163.

PESCHNER, J., FOTAKIS, C. (2013): Growth potential of EU human resources and policy implications for future economic growth, European Commission (DG EMPL) Working Paper 3/2013, http://ec.europa.eu/social/main.jsp?catId=738\&langId=en\&pubId=7662\&type=2\&f urtherPubs=no (2.9.2015).

PISON, G. (2008): Population trends in the United States and Europe: similarities and differences. Population \& Societies, 446, 1-4.

POLESNÁ, H., KOCOURKOVÁ, J. (2016): Je druhý demografický přechod stále relevantní concept pro evropské státy? Geografie, 121, 3, 390-418.

PRB (Population Reference Bureau; 2012): Data finder. Demographics. International Topics, http://www.prb.org/DataFinder (4.2.2013).

PRB (Population Reference Bureau; 2015): Data finder. Demographics. International Topics, http://www.prb.org/DataFinder (4.8.2015).

PRESTON, S.H., GLEI, D.A., WILMOTH, J.R. (2011): Contribution of Smoking to International Differences in Life Expectancy. In: National Research Council (ed.): International Differences in Mortality at Older Ages: Dimensions and Sources. Washington, DC, 105-131.

PRSKAWETZ, A., LINDH, T., eds. (2007): The Relationship between Demographic Change and Economic Growth in the EU. Research Report 32. Institut für Demographie, Vienna Institute of Demography. http://www.oeaw.ac.at/vid/download/FB32.pdf (26. 7. 2015).

RINCON-AZNAR, A., FOSTER-MCGREGOR, N., PÖSCHL, J., STEHRER, R., VECCHI, M., VENTURINI, F. (2014): Reducing Productivity and Efficiency Gaps: the Role of Knowledge Assets, Absorptive Capacity and Institutions, The Vienna Institute for International Economic Studies, Research Report 396, September 2014, http://wiiw.ac.at/reducing-productivityand-efficiency-gaps-the-role-of-knowledge-assets-absorptive-capacity-and-institutionscompetitiveness-report-2013--pj-26.html (3.9.2015).

RYCHTAŘíKOVÁ, J. (2015): Délka života, zdraví a postoje v Evropské unii. Geografie, 120, 4, 542-563.

SHRESTHA, L.B., HEISLER, E.J. (2011): The Changing Demographic Profile of the United States. In: Congressional Research Service. Washington, DC, http://digitalcommons.ilr.cornell.edu/ key_workplace/825/ (25.7.2015).

SOBOTKA, T. (2008): The diverse faces of the second demographic transition. In: Frejka, T.; Sobotka, T.; Hoem, J.M., Toulemon, L. (eds): Childbearing trends and policies in Europe. Demographic Research, 7, 19, 139-170.

Social Science Research Council (2017): Human Development Index, http://www.measureofamerica.org (23. 5. 2017).

STAETSKY, L. (2009): Diverging trends in female old-age mortality: A reappraisal. In: Demographic Research 33, 885-914.

SUTTON, P., MATHEWS, T.J. (2004): Trends in characteristics of births by state: United States, 1990, 1995, and 2000-2002. National Vital Statistics Report 52, 9. National Vital Statistics System and Centers for Disease Control., US Dept. of Health and Human Services.

STEPTOE, A., WIKMAN, A. (2011): The Contribution of Physical Activity to Divergent Trends in Longevity. In: National Research Council (ed.): International Differences in Mortality at Older Ages: Dimensions and Sources. Washington, DC, 193-216.

STEWART, S.T., CUTLER, D.M., ROSEN, A.B. (2009): Forecasting the Effects of Obesity and Smoking on U.S. Life Expectancy. New England Journal of Medicine, 361, 23, 2252-2260. 
U.S. National Center for Health Statistics (2017): National Vital Statistics Reports. Centers for Disease Control and Prevention, http://www.cdc.gov/nchs/nvss.htm (21. 5. 2017).

United Nations (2015): World Population Prospects: The 2015 Revision, DVD Edition. United Nations, Department of Economic and Social Affairs, Population Division, http://esa.un.org/ unpd/wpp/ (21. 5. 2017).

VAN ARK, B., CHEN, V., COLIJN, B., JAEGER, K., OVERMEER, W., TIMMER, M. (2013): Recent Changes in Europe's Competitive Landscape - How the Sources of Demand and Supply Are Shaping Up. European Economy, Economic Papers, 485, April 2013, http://ec.europa. eu/economy_finance/publications/economic_paper/2013/pdf/ecp485_en.pdf (3.9.2015). 